\title{
Phraseological units with a structural component of the zoonymic code in the assessment of human qualities in the Yakut and Chinese languages
}

\author{
Vera L. Moiseeva*, Alena Y. Ivanova \\ North-Eastern Federal University 58, Belinsky Street, Yakutsk, 977013, the Republic of Sakha (Yakutia), Russia
}

\begin{abstract}
The paper presents the attempt to perform comparative analysis of phraseological units with a structural component of the zoonymic code in the characterization of human qualities in the Yakut and Chinese languages. The paper analyzes the stereotypical images of animal characteristic of two countries with different geographic locations. The degree of similarity and difference in assessing the character of a person is of particular interest as well as the properties of his behavior, expressed metaphorically through the images of animals familiar to a certain national culture. Since, possessing linguistic and cultural differences, the speakers of the considered languages can attach different, sometimes diametrically opposite meanings to the same image. A comparative analysis of the idioms recorded in the language can help to reveal some culturally significant differences in the perception of one or another trait of human nature and the presentation of behavioral characteristics. The authors tried to consider the most common images for a given language and compare the anthropomorphic qualities attributed to this or that animal.
\end{abstract}

\section{Introduction}

\subsection{Specific features of the national culture}

In the linguistic culture of any ethno-national community, universal features inherent in a language can be traced, as well as ethnic patterns that characterize the cultural and national characteristics of each linguistic community. The subject of our research is phraseological units with a structural component of the zoonymic code in the characterization of human qualities in the Yakut and Chinese languages. The phraseological units with zoonyms reflect the oldest layer of the stereotypical concept of animals as carriers of certain qualities, character and behavior. This category of phraseological units represents a number of images that go back to the most ancient human ideas about nature, the ideas about the world through the creation of myths and the accumulated cognitive experience of human communication with the surrounding world and the animal world in particular.

For many centuries, the animal world and the human world existed in close proximity, going from a state of fierce competition for survival to relatively peaceful coexistence. The important stage in the development of these relations is the domestication of some wild animals (in order to use them for agricultural work, in which they acted as draft animals or animals for riding and transporting goods). Keeping and breeding animals for the production of food made it possible to provide human communities a more stable food source than hunting and fishing.

Certain types of domesticated animals began to protect man, guard his home and property, etc. As a result, in the human mind, animals are divided into enemies, prey, helpers and friends. Centuries-old observations of the life of the representatives of the local fauna allowed a person to form a certain idea of each of the animals known to him: its habits, lifestyle, and behavior. An animal for man was an akin and alien being at the same time.

Thus, the animal, according to V.M. Mokienko [1], was "a measure of many human qualities - both physical and moral". Comparing himself with an animal, a person found a lot in common and, gradually, through metaphorical transfer, assigned anthropomorphic characteristics to the images of animals: moral and ethical qualities, character traits, behavior patterns, mind properties.

At this stage, fairy tales were created, the heroes of which were animals that represent human qualities: strength and weakness, cunning and innocence, nobility and meanness; intelligence, wisdom, stupidity. Thus, in the national linguistic culture, stereotyped ideas about animals are recorded, each of which has its own set of moral qualities, traits, features, however, each linguistic culture can represent a separate animal in different ways.

Thus, in the Yakut language, fish has negative traits such as stupidity, slowness and lack of initiative, while in Chinese culture fish is a symbol of wealth and a carrier of wisdom. Therefore, the comparison with fish is

\footnotetext{
Corresponding author: velmo20@mail.ru
} 
not perceived in the same way among these two different peoples. In one case, such a comparison may be an insult, in the other - a praise, or it may not make sense at all. In this study, we make an attempt to identify common and national-specific features of the estimated value of phraseological units with a structural component of the zoonymic code, recorded in the dictionaries of two considered languages.

\subsection{Research object}

Intercultural communication of representatives of different cultural and national communities cannot be effective, even if the communicants speak the same language, but, at the same time, give different meanings to their statements. Without knowing the cultural background of the people, the country represented by an interlocutor, it is impossible to fully achieve real understanding, which implies a certain degree of common perception of the world, events, people and society.

The relevance of this study is explained by the fact that in the Republic of Sakha (Yakutia), there is currently a significantly increased interest in the study of the Chinese language and Chinese national culture. The practical value of the study is in the possibility of the use of its results when compiling phraseological dictionaries (the Yakut-Chinese, the Chinese-Yakut), as well as in the process of the formation of the cultural competence of students studying Chinese as a foreign language.

The study of any foreign language in all its depth and richness seems impossible without the analysis of the phraseology of studied language, since it is in the phraseological units that the originality of the national culture, the uniqueness of the historical development of the people and the formation of the nation's mentality are preserved in a frozen form. The phraseology of any national language is original and specific, since it reflects the subtlest nuances of the worldview of native speakers. The proverbs, sayings, popular expressions, mythologemes, which have been fixed in the language and preserved unchanged over the centuries, represent a richest resource not only for historical, but also for cultural studies.

The object of the research is the evaluative characteristic of a person in terms of his physical and moral qualities, behavior, attitude to various aspects of life, represented by the corresponding zoonym as a part of a phraseological unit in each of the studied languages.

We assume that:

1. In the Yakut and Chinese languages, there is a historically developed similar system for the assessment of a person by his behavior, habits, appearance and personal qualities.

2. Animals represent certain stereotypical properties that are perceived as positive or negative in the popular mind.

3. Phraseological units of the Yakut and Chinese languages may contain one and the same zoonym, symbolizing the same quality, describing the same traits of a human character.

As a result of a comparative analysis of phraseological units with a zoonym component, it is expected to determine possible similarities and differences in zoonymic images - carriers of certain anthropomorphic features and qualities.

\section{Materials and Methods}

The purpose of this research is to determine common and national specific features of phraseological units with a zoonym component, recorded in the linguistic corpus of the Yakut and Chinese languages, based on the structural-component composition of the phraseological unit and the axiological assessment of the actions and behavior of the considered metaphorical images of animals, represented by the zoonym component.

To achieve this goal, it is necessary to solve the following tasks:

1. To carry out the selection of phraseological units with a structural component-zoonym in each of the studied languages: Yakut, Chinese by the method of continuous sampling.

2. To conduct a comparative analysis of the selected phraseological units and determine the similarities and differences between the Yakut and Chinese idioms in terms of structural and component composition.

3. To determine national specific features in the assessment of the qualities of a person, expressed by phraseological units of each of the studied languages.

For this purpose, we used the following research methods:

1. Observation method

2. Method of continuous sampling

3. Comparative method

4. Descriptive method.

The source of the research material was the ChineseRussian, Yakut-Russian translation dictionaries, the Chinese-Russian, Yakut-Russian phraseological dictionaries, and explanatory dictionaries of the Yakut and Chinese languages.

The use of explanatory dictionaries was reasoned by the need to clarify the meaning of one or another phraseological unit or its part, since in some cases the etymology of the phraseological unit was unclear. In total, 4 translation dictionaries of the Yakut language, 2 phraseological dictionaries of the Yakut language, a large explanatory dictionary of the Yakut language and 2 phraseological dictionaries of the Chinese language were used.

\section{Results and Discussion}

As a result of the research, a large number of phraseological units with a zoonym component, representing certain qualities and properties of a human character, were found. This research of the material allows stating that:

1. In these two studied languages, there are similar axiological-evaluative systems of human character and behavior;

2. Phraseological units with a zoonym component 
express a positive or negative assessment of human character/behavior by metaphorical transfer of human qualities to the image of a certain animal;

3. Phraseological units of an evaluative nature in the Yakut and Chinese languages in some cases show complete coincidence (the image of the same animal in each of the studied languages represents the same properties and character traits. In other cases, a partial coincidence of the image of the animal and the qualities attributed to it is found. Thirdly some images represent completely different qualities in one language than in another).

In this study, we chose phraseological units with the most common zoonyms in the Chinese and Yakut languages. In the Yakut language, a large number of phraseological units are recorded using images of wild animals. This is due to the fact that since ancient times, the main traditional trade of the Yakuts has been hunting wild animals. In terms of frequency, images of a wolf, fox, hare, and sable prevail.

Thus, the image of a wolf is represented by a phraseological unit эһэ-бөрө сурэхтээх: with the heart of a wolf or a bear; thus they say about a person endowed with extraordinary courage and determination. A wise, experienced person is compared to an old, experienced beast: кырдьақас бөрө: old wolf. The following phraseological unit indicates the danger of a wild predator: бөрө (эһэ) тириитин кэт -to put on wolf (bear skin) - be angry. In the saying бөрөм бөтөһө, базам батаһa - my wolf bastard, my frog saber, a baby, a boy is compared simultaneously with an animal (wolf) and a plant (the Yakuts call the Siberian iris growing in a swampy area a frog saber).

Since this plant has a developed root system, it is very difficult to pull it out of the ground. A person trapped in a quagmire can get out of it by grabbing onto this plant. Phraseological unit is used as a praise for a child for strength and endurance. Unusual in this series of approving idioms is a phraseological unit with a pejorative coloration.

бөрө эмэһэтэ - wolf ass - which is used to express a disapproving, contemptuous attitude towards a chatterbox, a gossip. In this case, the use of reduced vocabulary, characteristic of the Yakut language, is used to express a negative and, as a consequence, disrespectful attitude towards the described phenomenon.

A bear, as the largest and most dangerous representative of the animal world in Yakutia, enjoyed the respectful and fearful attitude of the Yakut hunters.

Currently, the original name of the animal itself has been lost, for a long time it has been carefully called эһэgrandfather, out of fear, "calling" a dangerous predator by name, to attract his attention and be attacked.

In the few recorded idioms with the zoonym bear, it is noted that this animal does not lead a gregarious, solitary lifestyle, as well as his hot temper: икки adbblp5а эһэ биир ар5ахха кыстаабатmар -two male bears do not pass the winter at the same den, it is about rivalry between men. In later sayings эһэ кымырдаБастаабытыгар дыль - like a bear catching ants - to be engaged in frivolous, trifling business, and эһэ сиидэнэн уу баспытыгар дыль- like a bear scooped up water with a sieve, a bear appears to be a large, powerful and not very intelligent creature.

A fox in the Yakut culture is associated with a cunning, cautious person who is ready to deceive, betray, always pursuing his own selfish goals: саһьлл мэйии lit.: fox brain (about a cunning man), кэрэмэс саһьlл мэлдьэБэ -denial of a cross-fox (about a fraudster who does not admit his guilt, blatantly denies his guilt). Саһьл буолан ньылбый - look innocent like a fox - that is, to behave feigned humble, hypocritical. They say about a very careful person кырса-саһыл обото - baby fox or arctic fox.

The structural component of a hare, as expected, represents such qualities as fearfulness, cowardice: куобах сурэх-hare heart.

Zoonim sable is used for the highest praise to man, since this fur-bearing animal was considered the most valuable. Thus, the evaluative definition of the best, the outstanding, the first of is expressed in the phraseological unit киһи киэнэ кииһэ - the best of people, brave.

The circle of domestic animals among the Yakuts was not very diverse. Traditionally, a horse, a cow, a dog existed next to a person. Phraseological units with images of these animals describe different types of characters.

Thus, the zoonym cow represents the image of a meek, calm, good-natured person: cblmap blна5ы mуруорбат киһu - not raising (not frightening) even a cow; тарбаабыт ынах курдук -like a cow being scratched.

Horse symbolizes strength, speed, power. Thus, they say about a person with great physical strength: am бөБ$\theta$ - horse man.

Speaking about the zoonym $d o g$, it should be noted that in the Yakut language "almost all phraseological units referring to a dog denote negative signs, objects and actions". [2]. A morally low person is compared to a

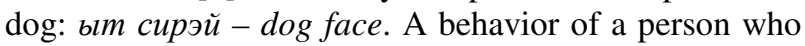
acts in inappropriately rude and offensive way is described by the phraseological unit blpдbblгblныlblp blm - growling dog. БIm курдук ньылланныьыр - like a bootlicking dog, - about a flattering man. An interesting idiom describing the behavior of a lazy person who pretends to be regularly performing his duties барбатаx ылт сыгынађы үрэригэр дылы - like a straggling dog barks on a windbreak.

In the curses, xapa mыbыннаax bim is a dog with black breath, түөрт харахтаax хара хааннаах хара blm - a four-eyed black dog with black blood. According to G.V. Ksenofontov [3], it is possible that the idea is reflected of the ancient Yakuts about a dog as a servant of the black, that is, evil, hostile to people, shaman.

Chinese phraseological units with a zoonymic code component surprise with the variety of suggested images. Thus, an idiom with a horse component denotes - tall and large 人高马大 rén gāo mă dà, and also 马不停 蹄 mă bù tíng tí - without respite, without stopping for a 
minute, tirelessly, that is, a person who is compared to a horse is distinguished not only by high growth, large body, but also by strength, endurance and speed. However, an image can have a pejorative coloration, when speed implies superficial perception, attitude to something: 走马观花 zǒumă guānhuā- gallop across Europe, fluently, superficially, briefly, literally admire the flowers at a gallop.

A cow / a bull is also represented in various idioms, for example, 九牛二虎之力 jiǔ niú èr hŭ zhì lì - strength of nine bulls and two tigers - about a person who has enormous physical strength and is able to perform very hard work. At the same time, there is a number of phraseological units that represent a bull as a stupid, dull animal, unable to appreciate high art: 对牛弹琴 duì niú tánqín - play the zither in front of a bull, (cast pearls before swine, another meaning is like talking to a brick wall). In some phraseological units, a bull represents evil, dark power: 牛头马面 niútóu mămiàn a bull head and a horse face (according to Buddhist mythology, two servants in the other world, one with the head of a bull, the other with a horse face) - they say about a disgusting, nasty person, ready for meanness.

A dog is reflected in a number of Chinese phraseological units, many of which contain negative characteristics. Thus, 狗仗人势 gǒu zhàng rén shì - a dog is protected by humans; it is about a person who behaves in a boorish way, unacceptably rude; this person is under the protection of a strong patron, this person offends others. Also, the image of a dog is used to describe a pretender, a deceiver: 人模狗样 rén mú góu yàng, rén mó gǒu yàng: he is a man, but behaves like a dog. Another considered phraseological unit is: 狼心狗 肺lángxīn gǒufèi- wolf heart and canine lungs, describes a cruel villain, devoid of conscience and humanity.

A tiger in Chinese phraseological units is presented as a large, very dangerous animal, which one should watch out for: 老虎头上搔棒: to scratch a tiger's head 摸老虎屁股mō lăohǔ pìn : to stroke a tiger's bottom. Both idioms correspond in meaning to the expressions to play with fire, to get on the rampage.

Another large wild animal, a wolf, has a negative characteristic in Chinese: 声名狼藉 shēngmíng lángjí: have a bad name, have a bad reputation.

Another zoonym image common in Chinese phraseology, a fox, represents a cunning person, a pretender: 露出狐狸尾巴 lùchū húli wéiba : to show true appearance; 狐狸哭兔子假慈悲: a fox cries for a rabbit - feigned compassion is described.

Today many works on the study of phraseological units with a zoonym component in the Yakut and Chinese languages have been registered. The authors such as Kulakovsky A.E., Nelunov A.G., Grigoriev N.S., Emelyanov N.V. in their works presented all the variety of phraseology in the Yakut national language, including detailed studies of the category of phraseological units with zoomorphic images. The phraseological worldview in Chinese is presented in the works: Jia Rong, Bi Yuhui, $\mathrm{Gu}$ Yan, Fan Imeng, Liu Yang. The works of these
Chinese authors are mainly related to the study of the phraseological corpus of the Russian language with the use of a comparative analysis of the phraseological units of the Chinese and Russian languages. Due to the research of these scientists, we have the opportunity to learn more about a number of phraseological units of the Chinese language.

\section{Conclusion}

We were the first to perform a comparative analysis of phraseological units with a structural component of the zoonymic code on the basis of two unrelated languages: Yakut and Chinese. As a result of our research, we found out that

1. In both studied languages, there is a system for the assessment of a person by his behavior, habits, appearance and personal character traits.

2. The images of animals represent certain stereotypical properties that are perceived as positive or negative in the popular mind.

3. The phraseological units of the Yakut and Chinese languages may contain the same zoonym component, expressing the same quality and describing the same traits of a human character.

In a number of cases, a simultaneous coincidence of images and characteristics expressed by the phraseological units of the Yakut and Chinese languages was revealed. For example, the zoonym $\operatorname{dog}$ in both linguistic cultures can symbolize pretense and deception. The image of a fox in both Yakut and Chinese is used to describe a cunning, selfish person. A horse in both languages is a symbol of strength and speed.

A bull personifies remarkable physical strength and, in some cases, stupidity. At the same time, some zoonyms represent a mismatch of characteristics: in one of the Chinese dictionary phraseological units, a bull is described as a representative of the dark force, a vile, disgusting creature. The considered Yakut phraseological units with bull component do not have such a connotation.

Some groups of phraseological units allowed revealing the existence of gaps. Thus, the Yakut zoonym sable has no figurative equivalent in Chinese. The nonequivalent vocabulary of Chinese phraseology is represented by the examples of zoonyms such as flea, monkey, turtle.

The etymology of the studied phraseological units is heterogeneous from language to language. The zoonyms presented by the phraseological corpus of the Yakut language are mainly the result of everyday observations of the behavior of animals in their natural habitat. They characterize the habits and behavior of real animals. In contrast to the studied Yakut phraseological corpus, the idioms of the Chinese language have a diverse origin, the source of many Chinese phraseological zoonyms is myths and fairy tales.

\section{References}


1. V.M. Mokienko On the methodology of a comparative study of Russian and German phraseology Rossica Olomucensia XXXVIII (za rok 1999). Univ. Palackèho Olomouci v roce, 92 (2000)

2. A.G. Nelunov Yakut - Russian Phraseological Dictionary (Novosibirsk, Publishing House of SB RAS1998)

3. G.V. Ksenophontov, Shamanism, retrieved from: http://www.niknet.itkm.ru/Ksenofontov_G_V_Sh amanizm_Izbrannye_trudy.pdf (2009)

4. Bi Yuhui. Comparative translation of RussianChinese proverbs and phraseology Bulletin of Social Sciences of Jilin University (1995)

5. R.N. Anisimov Zoomorphic components in the phraseological units of the Yakut language characterizing a person Siberian Journal of Philology, 4 (2016)

6. Big explanatory dictionary of the Yakut language, 1-10 (Novosibirsk, Nauka, 2007-2014)

7. E.N. Mushnikova, Zoometaphor in the linguistic worldview of the Russian and English languages, News of universities. Volga region. Humanities, 4 (2011)

8. O.M. Gottlieb, Mu Huayin Chinese-Russian Phraseological Dictionary, (ISU Publishing House, 2019)

9. Ju Chuanting, Mental characteristics of paremias with a zoonym in Russian and Chinese, Meteor City, 2 (8) (2017)

10. A.A. Mironova, Ju Chuanting, Reflection of gender-relevant information in Russian and Chinese paremias with the animal component Chelyabinsk Humanities, 4 (41) (2017) 